\title{
Modeling and Optimization of Electrocoagulation Process for the Removal of Yellow145 dye Based on Central Composite Design
}

\author{
Abdul Rauf Shah, Hajira Tahir ${ }^{*}$ and Sonia Sadiq \\ Department of Chemistry, University of Karachi-75270, Karachi, Pakistan. \\ *Corresponding Author Email: hajirat@uok.edu.pk \\ Received 06 February 2019, Revised 06 November 2019, Accepted 10 November 2019
}

\begin{abstract}
In this study, Central Composite Design (CCD) approach of Response Surface Methodology (RSM) was applied to develop a mathematical model and to optimize the parameters of electrocoagulation process (EC) for the removal of Yellow145 (Y145) dye. The EC process was studied by using coupled electrodes of $\mathrm{Fe}-\mathrm{Fe}$ and $\mathrm{Al}-\mathrm{Al}$, separately. The operational parameters of the process such as dye concentration, $\mathrm{pH}$, electrolysis time and amount of $\mathrm{NaCl}$ were studied to obtain their desired levels for getting the high value of the removal of the dye. The values of correlation coefficient $\left(\mathrm{R}^{2}\right)$ of the model were found to be $81.71 \%, 56.93 \%$ for $\mathrm{Fe}-\mathrm{Fe}$ and $\mathrm{Al}-\mathrm{Al}$, respectively. Analysis of variance (ANOVA) helped in finding the significant variables of the process. The response surface plots were plotted to observe the interaction between the levels of the factors on the response of the process.
\end{abstract}

Keywords: Electrocoagulation process, Response surface methodology, Central composite design, Yellow145, FTIR, Cost analysis.

\section{Introduction}

The textile industrial sector consumes large volume of water during dyeing and finishing operations. This sector also discharges large portion of effluent into the natural resources of water. The textile effluent contains many dyes which cause environmental and health problems. Azo dyes are used in the textile, paint, ink and plastic industries. These dyes show stability against bio-degradation [1-4]. Electrochemicalbased systems are controlled and rapid process. They need only electrons to treat wastewater. They do not require chemicals and micro-organisms $[5,6]$. Among the electrochemical techniques, (EC) process has a wide applications for the treatment of industrial effluents.

The theory of EC and chemical coagulation is almost similar. In EC, the coagulant of $\mathrm{Al}^{3+}, \mathrm{Fe}^{3+}$ ions are supplied by applying an electric current to the metal anodes kept in a EC reactor [7, 8]. Firstly, the metal anode is oxidized as follows:

$$
\mathrm{M}_{(\mathrm{S})} \longrightarrow \mathrm{M}_{(\mathrm{aq})}{ }^{\mathrm{n}+}+\mathrm{ne}^{-}
$$

Additionally, the electrolysis of water takes place at the cathode and anode as follows:

$$
\begin{aligned}
& 2 \mathrm{H}_{2} \mathrm{O}_{(\mathrm{l})}+2 \mathrm{e}^{-} \longrightarrow \mathrm{H}_{2(\mathrm{~g})}+2 \mathrm{OH}^{-} \text {at cathode } \\
& 2 \mathrm{H}_{2} \mathrm{O}_{(\mathrm{l})} \longrightarrow 4 \mathrm{H}^{+}+\mathrm{O}_{2(\mathrm{~g})}+4 \mathrm{e}^{-} \text {at anode }
\end{aligned}
$$

The formed chemical species of dissolved metal cations destabilize the contaminants, particulate suspension, and also break emulsions. The generation of hydrogen gas is also promote the 
floatation process to remove the flocculated particles out of the water.

Furthermore, the hydroxide ions formed at the cathode increase the $\mathrm{pH}$ of the EC system and induce the formation of precipitates of metal ions with the hydroxides as follows:

$\mathrm{M}_{(\mathrm{aq})}{ }^{\mathrm{n}+}+\mathrm{nOH}^{-} \longrightarrow \mathrm{M}(\mathrm{OH})_{\mathrm{n}(\mathrm{s})}$

Eventually, the destabilized particles in the EC system undergo aggregation to form flocs [9].

In case of using iron electrodes, the following two mechanisms have been proposed for the formation of the metal hydroxide [10]:

\section{Mechanism-1}

The reactions at anode:

$4 \mathrm{Fe}_{(\mathrm{S})}+8 \mathrm{e}^{-} \longrightarrow 4 \mathrm{Fe}^{+2}{ }_{(\mathrm{aq})}$

$4 \mathrm{Fe}^{+2}+10 \mathrm{H}_{2} \mathrm{O}+\mathrm{O}_{2} \longrightarrow 4 \mathrm{Fe}(\mathrm{OH})_{3(\mathrm{~S})}+8 \mathrm{H}^{+}$

The reactions at cathode:

$8 \mathrm{H}^{+}+8 \mathrm{e}^{-} \longrightarrow 4 \mathrm{H}_{2(\mathrm{~g})}$

Overall reactions:

$4 \mathrm{Fe}_{(\mathrm{S})}+10 \mathrm{H}_{2} \mathrm{O}+\mathrm{O}_{2} \longrightarrow 4 \mathrm{Fe}(\mathrm{OH})_{3(\mathrm{~S})}+4 \mathrm{H}_{2(\mathrm{~g})}$

$\mathrm{nFe}(\mathrm{OH})_{3(\mathrm{~S})} \longrightarrow \mathrm{Fe}_{\mathrm{n}}(\mathrm{OH})_{3 \mathrm{n}(\mathrm{s})}$

\section{Mechanism-2}

The reaction at anode:

$\mathrm{Fe}_{(\mathrm{S})}-2 \mathrm{e}^{-} \longrightarrow \mathrm{Fe}^{+2}($ aq $)$

$\mathrm{Fe}_{(\mathrm{aq})}^{+2}+2 \mathrm{OH}^{-} \longrightarrow \mathrm{Fe}(\mathrm{OH})_{2}$

The reaction at cathode:

$2 \mathrm{H}_{2} \mathrm{O}+2 \mathrm{e}^{-} \longrightarrow 2 \mathrm{OH}^{-}+4 \mathrm{H}_{2(\mathrm{~g})}$

Overall reactions:

$\mathrm{Fe}_{(\mathrm{S})}+2 \mathrm{H}_{2} \mathrm{O} \longrightarrow \mathrm{Fe}(\mathrm{OH})_{2}+\mathrm{H}_{2(\mathrm{~g})}$

$\mathrm{nFe}(\mathrm{OH})_{2(\mathrm{~S})} \longrightarrow \mathrm{Fe}_{\mathrm{n}}(\mathrm{OH})_{2 \mathrm{n}(\mathrm{s})}$

The way of removing dye from wastewater.

\section{Precipitation:}

Dye+[Monomeric Fe ] $\longrightarrow$ [Dye -Monomeric Fe ](15)

Dye + Polymeric-Fe $\longrightarrow$ [Dye -Polymeric Fe]

Adsorption:

Dye $+\mathrm{Fe}_{\mathrm{n}}(\mathrm{OH})_{\mathrm{n}} \longrightarrow$ Sludge $(\mathrm{s})$

$\left[\right.$ Dye -Polymeric Fe ] $+\mathrm{Fe}_{\mathrm{n}}(\mathrm{OH})_{\mathrm{n}} \longrightarrow$ Sludge(s)
The main reactions at the electrodes in case of Al-Al electrodes combination are:

$\mathrm{Al} \longrightarrow \mathrm{Al}^{+3}$ at anode

$3 \mathrm{H}_{2} \mathrm{O}+3 \mathrm{e}^{-} \longrightarrow 3 / 2 \mathrm{H}_{2}+3 \mathrm{OH}^{-}$at cathode

At high $\mathrm{pH}$, the formation of hydrogen gas at the cathode generates $\mathrm{OH}^{-}$ions [11].

$2 \mathrm{Al}+6 \mathrm{H}_{2} \mathrm{O}+2 \mathrm{OH}^{-} \longrightarrow 2 \mathrm{Al}(\mathrm{OH})_{4}{ }^{-}+3 \mathrm{H}_{2}$

The formed aluminium and hydroxide ions react to form various monomeric species which are finally changed into $\mathrm{Al}(\mathrm{OH})_{3}$ according to complex precipitation kinetics. The following interaction mechanisms are possible between the molecules of a dye and hydrolysis by-products $[12,13]$.

Precipitation:

Dye $+[$ Monomeric $\mathrm{Al}] \longrightarrow[$ Dye -Monomeric

Al]s, $\mathrm{pH}=4-5$

Dye+PolymericAl $\longrightarrow[$ Dye-Polymeric Al]s,

$\mathrm{pH}=5-6$

Adsorption:

Dye $+\mathrm{Al}(\mathrm{OH})_{3} \longrightarrow$ Particle

$[$ Dye -Polymeric $\mathrm{Al}] \mathrm{s}+\mathrm{Al}(\mathrm{OH})_{3(\mathrm{~s})} \longrightarrow$ Particle

These flocs polymerise as :

$\mathrm{nAl}(\mathrm{OH})_{3} \longrightarrow \mathrm{Al}_{\mathrm{n}}(\mathrm{OH})_{3 \mathrm{n}}$

In EC process the excessive amount of coagulants is not added owing to their direct generation by electro-oxidation of a sacrificial anode. EC equipment is simple and easy to operate and also require short reaction time and low sludge production [14].

The EC process is optimized to determine the best levels of the factors to get maximum efficiency of the process in the treatment of aqueous discharges. Recently, the experiments based on statistical design are used to determine interactions among the factors to optimize the operating parameters in multivariable analysis. They are also used to obtain statistically significant models by performing the minimum number of experiments. RSM is used for modeling and optimizing a response of a process. It is also analyzed the ways in which several variables influence a response of interest [15]. The CCD, the 
design under RSM, is an efficient method. It provides more detailed information regarding the data obtained from a treatment process in fewer number of experiments. This article present the results of the laboratory scale studies on the removal of Y145 dye from simulated wastewater using coupled iron-iron ( $\mathrm{Fe}-\mathrm{Fe})$ and aluminiumaluminium ( $\mathrm{Al}-\mathrm{Al})$ electrodes by EC process. The study will provide guidance in operating and designing reactors for the treatment of large volume of wastewater.

\section{Materials and Methods Experimental Setup and Procedure}

A laboratory-scale glass EC setup was used. For each test, a $1000 \mathrm{~mL}$ of Y145 dye sample was used. Before each run, acetone was used to wash the electrodes and the impurities were removed by dipping in a solution of $\mathrm{HCl}$ solution [16]. All the chemicals used to be of analyticalreagent grade. The EC experiments were conducted by applying a voltage of $15 \mathrm{~V}$ by means of a DC power supply (Yaxun 1502DD; 15V, 2A). At the end of each run, the sample was collected and filtered to remove floated and precipitated materials. After that, the filtrate was analyzed with T80 UV/VIS spectrophotometer. The dye and the obtained sludge were characterized by FTIR model NICOLET 6700 [17].

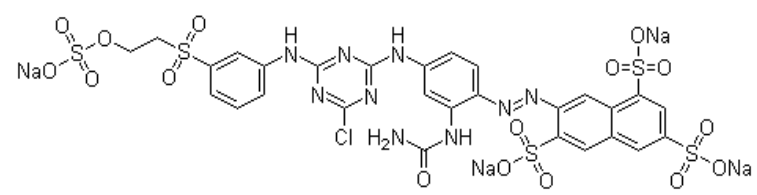

Figure 1. The structure of Y145 dye

\section{Experimental Design and Model Development}

The optimum levels of the factors of EC process were found in three analytical steps; adequacy of various model tests (sequential model sum of squares and model summary statistics), ANOVA, and the response surface plotting for the removal of Y145 from simulated wastewater. The data were analyzed with the Minitab Software 17. A total of 31 experiments were conducted in this study. The levels of the variables are given in Table 1. Table 2 is representing the treatments and corresponding the removal of Y145 by using two separate electrodes systems. The linear, quadratic, and combined effects of the operational parameters on the removal of the dye were described by a second-order polynomial as given below:

$\mathrm{Y}=\beta_{\mathrm{o}}+\sum_{\mathrm{i}=1}^{4} \beta_{\mathrm{i}} \mathrm{x}_{\mathrm{i}}+\sum_{\mathrm{i}=1}^{4} \sum_{\mathrm{j}=1}^{4} \beta_{\mathrm{ij}} \mathrm{x}_{\mathrm{i}} \mathrm{x}_{\mathrm{j}}+\sum_{\mathrm{i}=1}^{4} \beta_{\mathrm{ii}} \mathrm{x}_{\mathrm{i}}^{2}$

Table 1. The levels of the factors of EC process.

\begin{tabular}{lccccc}
\hline $\begin{array}{l}\text { Independent } \\
\text { Variables }\end{array}$ & $\boldsymbol{- \infty}$ & $\mathbf{- 1}$ & $\mathbf{0}$ & $\mathbf{+ 1}$ & $\mathbf{+}$ \\
\hline $\begin{array}{l}{[\mathrm{A}][\text { dye }]} \\
(\mathrm{mg} / \mathrm{L})\end{array}$ & 100 & 150 & 200 & 250 & 300 \\
& & & & & \\
{$[\mathrm{~B}] \mathrm{NaCl}(\mathrm{g} / \mathrm{L})$} & 1 & 1.25 & 1.5 & 1.75 & 2 \\
{$[\mathrm{C}] \mathrm{pH}$} & 3 & 5 & 7 & 9 & 11 \\
{$[\mathrm{D}]$} & 10 & 15 & 20 & 25 & 30 \\
$\begin{array}{l}\text { Electrolysis } \\
\text { Time (min) }\end{array}$ & & & & & \\
\hline
\end{tabular}

Table 2. The full-factorial design used for the removal of Y145 dye using EC.

\begin{tabular}{|c|c|c|c|c|c|}
\hline $\begin{array}{c}\text { dye] } \\
(\mathrm{mg} / \mathrm{L})\end{array}$ & $\begin{array}{l}\mathrm{NaCl} \\
(\mathrm{g} / \mathrm{L})\end{array}$ & pH & $\begin{array}{c}\text { Electrolysis } \\
\text { Time } \\
(\mathrm{min}) \\
\end{array}$ & $\mathrm{Fe}-\mathrm{Fe}$ & Al-Al \\
\hline 250 & 1.25 & 9 & 15 & 100 & 83 \\
\hline 250 & 1.75 & 5 & 25 & 100 & 92 \\
\hline 150 & 1.25 & 9 & 25 & 100 & 87 \\
\hline 250 & 1.25 & 9 & 25 & 100 & 82 \\
\hline 100 & 1.5 & 7 & 20 & 96 & 87 \\
\hline 250 & 1.75 & 9 & 25 & 100 & 90 \\
\hline 150 & 1.75 & 5 & 25 & 96 & 87 \\
\hline 200 & 1.5 & 7 & 10 & 100 & 99 \\
\hline 200 & 1.5 & 7 & 20 & 99 & 80 \\
\hline 300 & 1.5 & 7 & 20 & 100 & 52 \\
\hline 250 & 1.25 & 5 & 15 & 96 & 87 \\
\hline 150 & 1.25 & 5 & 15 & 100 & 92 \\
\hline 250 & 1.25 & 5 & 25 & 96 & 87 \\
\hline 250 & 1.75 & 5 & 15 & 100 & 95 \\
\hline 200 & 1.5 & 7 & 20 & 100 & 96 \\
\hline 200 & 2 & 7 & 20 & 93 & 75 \\
\hline 150 & 1.75 & 9 & 15 & 89 & 94 \\
\hline 150 & 1.25 & 9 & 15 & 97 & 78 \\
\hline 200 & 1.5 & 7 & 30 & 100 & 81 \\
\hline 200 & 1.5 & 7 & 20 & 99 & 87 \\
\hline 150 & 1.25 & 5 & 25 & 100 & 92 \\
\hline 200 & 1.5 & 11 & 20 & 100 & 89 \\
\hline 150 & 1.75 & 9 & 25 & 94 & 83 \\
\hline 200 & 1.5 & 7 & 20 & 96 & 86 \\
\hline 250 & 1.75 & 9 & 15 & 99 & 76 \\
\hline 200 & 1.5 & 7 & 20 & 96 & 86 \\
\hline 200 & 1.5 & 3 & 20 & 95 & 99 \\
\hline 200 & 1.5 & 7 & 20 & 100 & 76 \\
\hline 200 & 1.5 & 7 & 20 & 96 & 86 \\
\hline 200 & 1 & 7 & 20 & 100 & 81 \\
\hline 150 & 1.75 & 5 & 15 & 94 & 93 \\
\hline
\end{tabular}


Where $Y$ is the predicted response and considered as a dependent variable. The $X_{i}$ and $X_{j}$ show the independent variables. While, $\beta$ is the constant coefficient, and $\beta_{i}, \beta_{i j}$ and $\beta_{i i}$ are the coefficients of linear, interaction and quadratic terms, respectively [18].

\section{Results and Discussion}

\section{Statistical Analysis and Optimization} EC process using Fe-Fe and Al-Al electrodes

The experimental results obtained by CCD were fitted to the second-order (quadratic) polynomial response surface model. The following regression equations with the coded variables were obtained using $\mathrm{Fe}-\mathrm{Fe}$ and $\mathrm{Al}-\mathrm{Al}$ electrodes for the removal of Y145 dye:

$\mathrm{Fe}-\mathrm{Fe}=134.1-0.2260 \mathrm{~A}-8.3 \mathrm{~B}+0.28 \mathrm{C}-0.823$

D- 0.000029 AA- 7.17BB - $0.0495 \mathrm{CC}+0.0171$

$\mathrm{DD}+0.1550 \mathrm{AB}+0.01062 \mathrm{AC}-0.00225 \mathrm{AD}-$ $1.625 \mathrm{BC}+0.250 \mathrm{BD}+0.0437 \mathrm{CD}$

$\mathrm{Al}-\mathrm{Al}=112+0.341 \mathrm{~A}+57.6 \mathrm{~B}-14.00 \mathrm{C}-$
4.09D - 0.001279 AA - 17.1 BB + 0.732

$\mathrm{CC}+0.0771 \mathrm{DD}+0.030 \mathrm{AB}-0.0050 \mathrm{AC}$

$+0.00450 \mathrm{AD}+0.50 \mathrm{BC}-0.70 \mathrm{BD}$

$+0.125 \mathrm{CD}$

The synergistic effect of the factors is shown by the positive sign of the coefficients in equation $(28,29)$, whereas the negative sign suggests antagonistic effect [18].

Statistical testing of the model was evaluated by the ANOVA. The data are tabulated in Table 3. It can be noted that the regression model was significant for Fe-Fe electrodes, while insignificant for Al-Al electrodes. The significance of the parameters is given in Table 4. It was also encountered that the concentration of the dye (A), and amount of electrolyte (B) were showing linearly and combined effects on the removal of the dye in Fe-Fe electrodes system. In the second electrode system, the concentration of the dye (A) has a linear and quadratic effect on the removal of the dye. The significance of the model can be analyzed in Table 5 [19-24].

Table 3. ANOVA for the removal of Y145 dye using Fe-Fe and Al-Al electrode combinations.

\begin{tabular}{|c|c|c|c|c|c|c|c|c|c|c|}
\hline \multirow[b]{2}{*}{ Source } & \multicolumn{5}{|c|}{$\mathrm{Fe}-\mathrm{Fe}$} & \multicolumn{5}{|c|}{ Al-Al } \\
\hline & $D F$ & Adj $S S$ & AdjMS & F-Value & P-Value & $D F$ & Adj $S S$ & AdjMS & F-Value & P-Value \\
\hline Model & 14 & 194.003 & 13.8573 & 5.11 & 0.001 & 14 & 1383.34 & 98.81 & 1.51 & 0.213 \\
\hline Linear & 4 & 82.167 & 20.5417 & 7.57 & 0.001 & 4 & 562.33 & 140.5 & 2.15 & 0.122 \\
\hline A & 1 & 35.042 & 35.0417 & 12.91 & 0.002 & 1 & 294.00 & 294.0 & 4.49 & 0.050 \\
\hline B & 1 & 40.042 & 40.0417 & 14.76 & 0.001 & 1 & 4.17 & 4.167 & 0.06 & 0.804 \\
\hline $\mathrm{C}$ & 1 & 2.042 & 2.0417 & 0.75 & 0.399 & 1 & 216.00 & 216.0 & 3.30 & 0.088 \\
\hline $\mathrm{D}$ & 1 & 5.042 & 5.0417 & 1.86 & 0.192 & 1 & 48.17 & 48.16 & 0.74 & 0.404 \\
\hline Square & 4 & 13.461 & 3.3653 & 1.24 & 0.334 & 4 & 756.26 & 189.0 & 2.89 & 0.056 \\
\hline AA & 1 & 0.152 & 0.1520 & 0.06 & 0.816 & 1 & 292.17 & 292.2 & 4.47 & 0.051 \\
\hline $\mathrm{BB}$ & 1 & 5.737 & 5.7371 & 2.11 & 0.165 & 1 & 32.83 & 32.82 & 0.50 & 0.489 \\
\hline $\mathrm{CC}$ & 1 & 1.120 & 1.1201 & 0.41 & 0.530 & 1 & 245.25 & 245.2 & 3.75 & 0.071 \\
\hline DD & 1 & 5.216 & 5.2159 & 1.92 & 0.185 & 1 & 106.36 & 106.3 & 1.63 & 0.220 \\
\hline 2-Way Interaction & 6 & 98.375 & 16.3958 & 6.04 & 0.002 & 6 & 64.75 & 10.79 & 0.16 & 0.983 \\
\hline $\mathrm{AB}$ & 1 & 60.062 & 60.0625 & 22.13 & 0.000 & 1 & 2.25 & 2.250 & 0.03 & 0.855 \\
\hline $\mathrm{AC}$ & 1 & 18.063 & 18.0625 & 6.66 & 0.020 & 1 & 4.00 & 4.000 & 0.06 & 0.808 \\
\hline $\mathrm{AD}$ & 1 & 5.062 & 5.0625 & 1.87 & 0.191 & 1 & 20.25 & 20.25 & 0.31 & 0.586 \\
\hline $\mathrm{BC}$ & 1 & 10.563 & 10.5625 & 3.89 & 0.066 & 1 & 1.00 & 1.000 & 0.02 & 0.903 \\
\hline $\mathrm{BD}$ & 1 & 1.562 & 1.5625 & 0.58 & 0.459 & 1 & 12.25 & 12.250 & 0.19 & 0.671 \\
\hline $\mathrm{CD}$ & 1 & 3.062 & 3.0625 & 1.13 & 0.304 & 1 & 25.00 & 25.000 & 0.38 & 0.545 \\
\hline Error & 16 & 43.417 & 2.7135 & $*$ & $*$ & 16 & 1046 & 65.41 & $*$ & $*$ \\
\hline Lack-of-Fit & 10 & 21.417 & 2.1417 & 0.58 & 0.784 & 10 & 813.17 & 81.32 & 2.09 & 0.190 \\
\hline Pure Error & 6 & 22.000 & 3.6667 & $*$ & $*$ & 6 & 233.43 & 38.905 & $*$ & $*$ \\
\hline Total & 30 & 237.419 & $*$ & $*$ & $*$ & 30 & 2429.94 & $*$ & $*$ & $*$ \\
\hline
\end{tabular}


Table 4. Student $\mathrm{t}$ and p-values for the removal of Y145 dye using Fe-Fe and Al-Al electrode combinations.

\begin{tabular}{|c|c|c|c|c|c|c|c|c|c|c|c|c|}
\hline \multirow[b]{2}{*}{ Term } & \multicolumn{6}{|c|}{ Fe-Fe } & \multicolumn{6}{|c|}{ Al-Al } \\
\hline & Effect & Coef & SECoef & T-Value & P-Value & VIF & Effect & Coef & SECoef & T-Value & P-Value & $V I F$ \\
\hline Constant & & 98.00 & 0.623 & 157.40 & 0.000 & & & 85.29 & 3.06 & 27.90 & 0.000 & \\
\hline A & 2.417 & 1.208 & 0.336 & 3.590 & 0.002 & 1.00 & -7.00 & -3.50 & 1.65 & -2.12 & 0.050 & 1.00 \\
\hline B & -2.583 & -1.292 & 0.336 & -3.840 & 0.001 & 1.00 & 0.83 & 0.42 & 1.65 & 0.25 & 0.804 & 1.00 \\
\hline $\mathrm{C}$ & 0.583 & 0.292 & 0.336 & 0.870 & 0.399 & 1.00 & -6.00 & -3.00 & 1.65 & -1.82 & 0.088 & 1.00 \\
\hline $\mathrm{D}$ & 0.917 & 0.458 & 0.336 & 1.360 & 0.192 & 1.00 & -2.83 & -1.42 & 1.65 & -0.86 & 0.404 & 1.00 \\
\hline AA & -0.146 & -0.073 & 0.308 & -0.240 & 0.816 & 1.03 & -6.39 & -3.20 & 1.51 & -2.11 & 0.051 & 1.03 \\
\hline $\mathrm{BB}$ & -0.896 & -0.448 & 0.308 & -1.450 & 0.165 & 1.03 & -2.14 & -1.07 & 1.51 & -0.71 & 0.489 & 1.03 \\
\hline $\mathrm{CC}$ & -0.396 & -0.198 & 0.308 & -0.640 & 0.530 & 1.03 & 5.86 & 2.93 & 1.51 & 1.94 & 0.071 & 1.03 \\
\hline DD & 0.854 & 0.427 & 0.308 & 1.390 & 0.185 & 1.03 & 3.86 & 1.93 & 1.51 & 1.28 & 0.220 & 1.03 \\
\hline $\mathrm{AB}$ & 3.875 & 1.937 & 0.412 & 4.700 & 0.000 & 1.00 & 0.75 & 0.37 & 2.02 & 0.19 & 0.855 & 1.00 \\
\hline $\mathrm{AC}$ & 2.125 & 1.062 & 0.412 & 2.580 & 0.020 & 1.00 & -1.00 & -0.50 & 2.02 & -0.25 & 0.808 & 1.00 \\
\hline $\mathrm{AD}$ & -1.125 & -0.562 & 0.412 & -1.370 & 0.191 & 1.00 & 2.25 & 1.12 & 2.02 & 0.56 & 0.586 & 1.00 \\
\hline BC & -1.625 & -0.812 & 0.412 & -1.970 & 0.066 & 1.00 & 0.50 & 0.25 & 2.02 & 0.12 & 0.903 & 1.00 \\
\hline $\mathrm{BD}$ & 0.625 & 0.313 & 0.412 & 0.760 & 0.459 & 1.00 & -1.75 & -0.87 & 2.02 & -0.43 & 0.671 & 1.00 \\
\hline $\mathrm{CD}$ & 0.875 & 0.437 & 0.412 & 1.060 & 0.304 & 1.00 & 2.50 & 1.25 & 2.02 & 0.62 & 0.545 & 1.00 \\
\hline
\end{tabular}

Table 5. Model summary of EC process for the removal of Y145 dye.

\begin{tabular}{ccc}
\hline Statistical parameters & Fe-Fe & Al-Al \\
\hline $\mathrm{S}_{(\text {square mean of error) }}$ & 1.647 & 8.088 \\
$\mathrm{R}^{2}$ & $81.71 \%$ & $56.93 \%$ \\
$\mathrm{R}^{2}(\mathrm{adj})$ & $65.71 \%$ & $19.24 \%$ \\
$\mathrm{R}^{2}(\mathrm{pred})$ & $35.43 \%$ & $0.000 \%$ \\
\hline
\end{tabular}

\section{Residual plots}

In the normal probability plots the data were around the normal line it mean the second order polynomial model was well fitted to the data. The residuals were lying between 1 to -1 in $\mathrm{Fe}-\mathrm{Fe}$ electrode system while in Al-Al electrode system the residuals were between 10 to -10 . The residual plots are shown in Fig. 2-3.

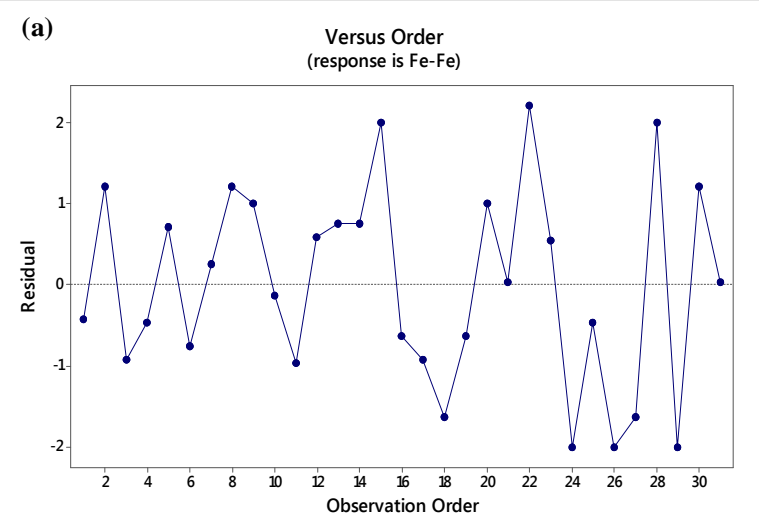

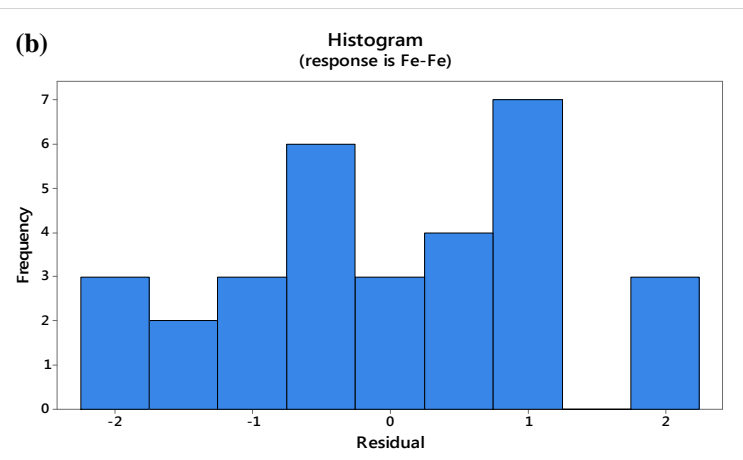

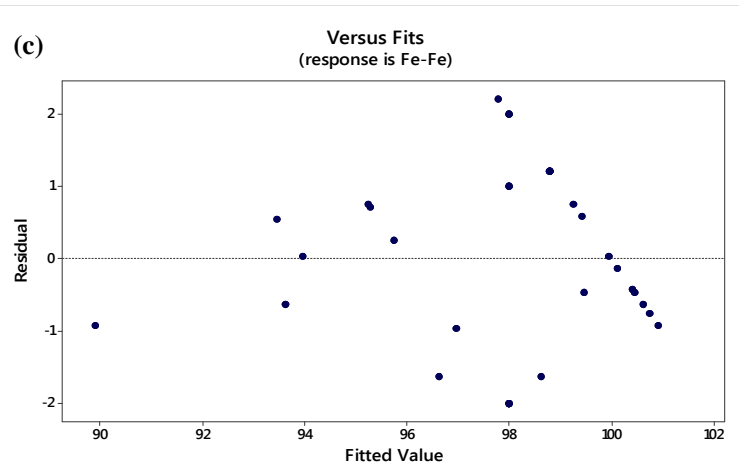


(d)

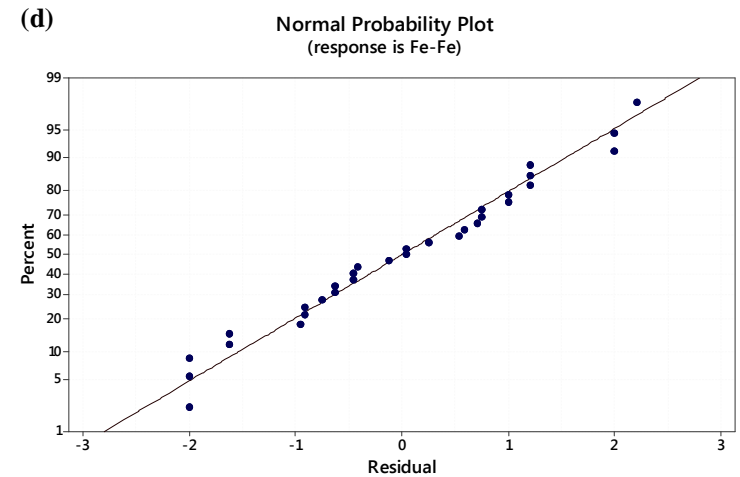

Figure 2. Residual plots for the removal of Y145 dye using Fe-Fe electrodes

(a)
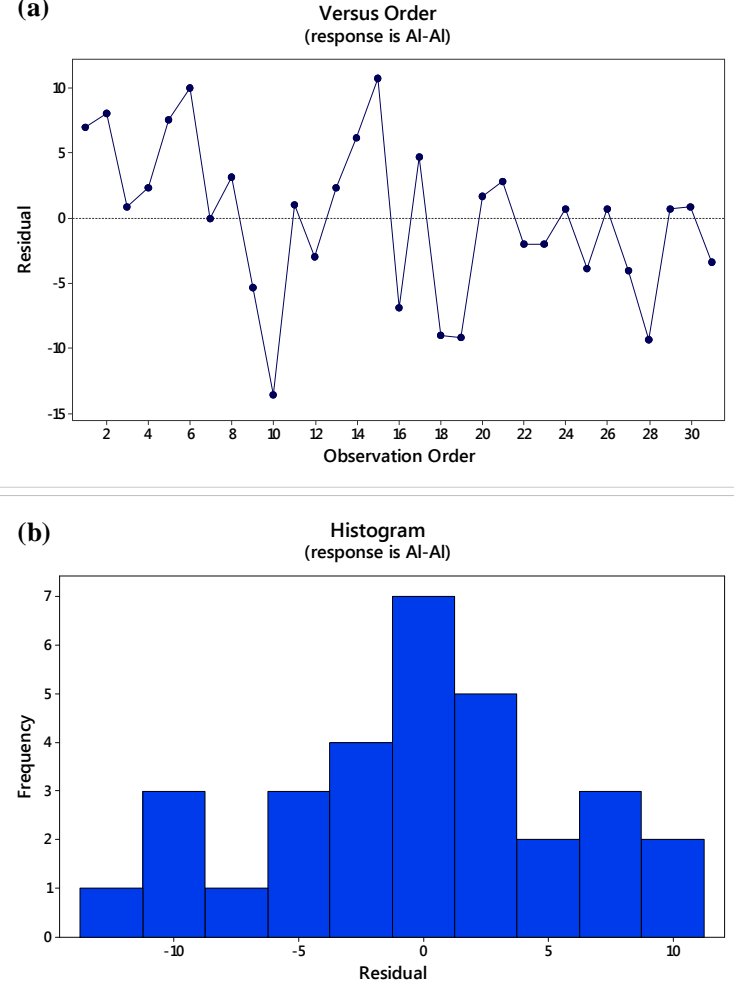

(c)

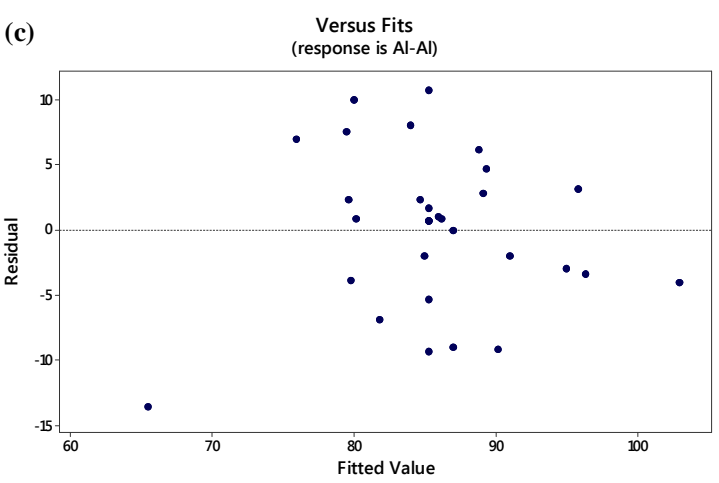

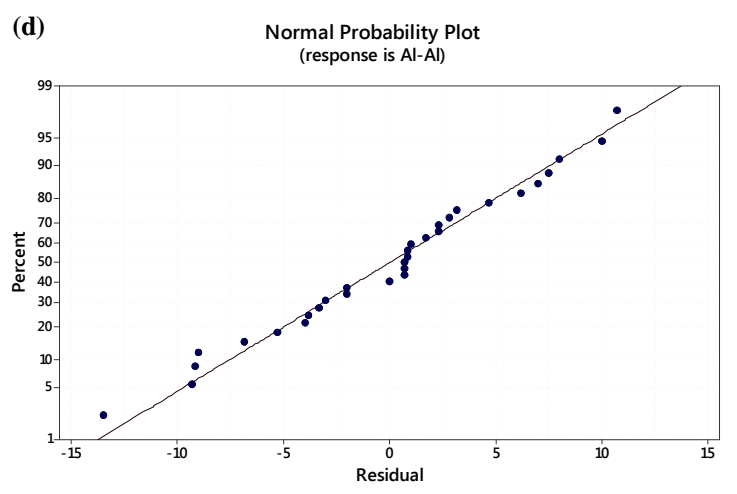

Figure 3. Residual plots for the removal of Y145 dye using Al-Al electrodes

The desired levels of the variables of the process are given in Fig. 4.
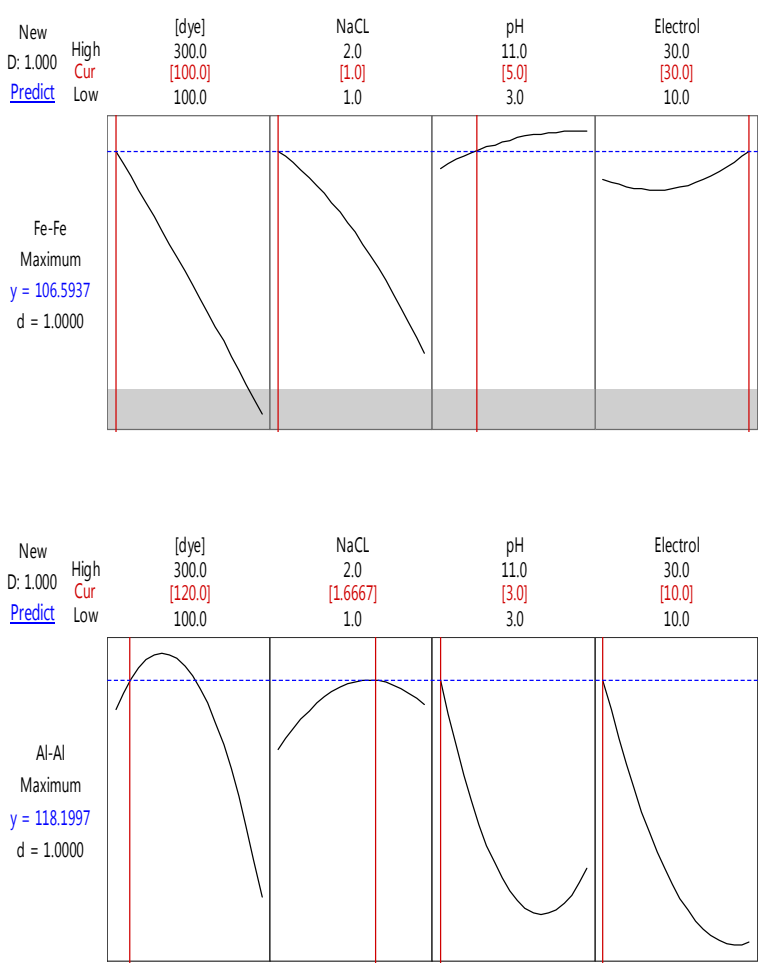

Figure 4. Optimum operating conditions of the process

\section{Main interaction plots}

The main interaction plots were showed that as the levels of the factors were changing the removal of Y145 dye was also changing. It was more prominent in $\mathrm{Fe}-\mathrm{Fe}$ electrode system as compared to Al-Al electrode system as shown in Fig 5a-b. 

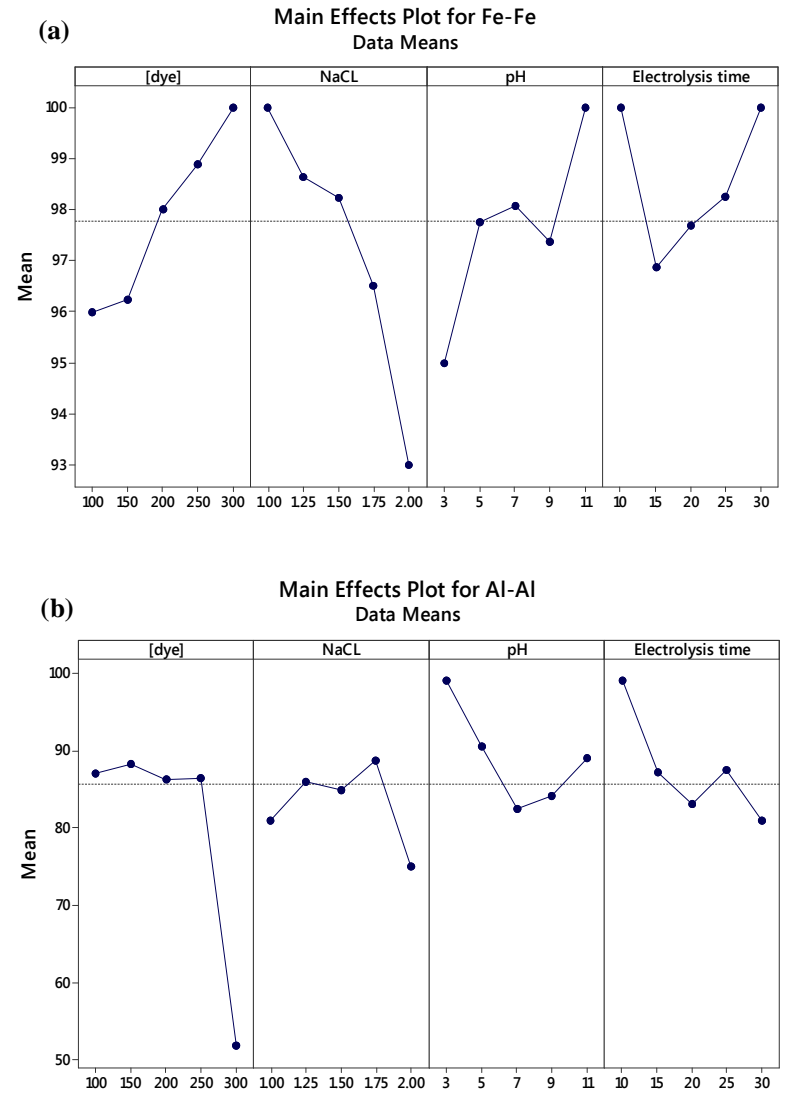

Figure 5. Main effect plots

\section{Full interaction plots}

The lines in the full interaction plots were not parallel to both $\mathrm{X}$-axis and $\mathrm{Y}$-axis. This indicated that the levels of the factors were varying the removal of Y145 dye during the EC process using $\mathrm{Fe}-\mathrm{Fe}$ and $\mathrm{Al}-\mathrm{Al}$ electrodes systems as shown in Fig. 6a-b.

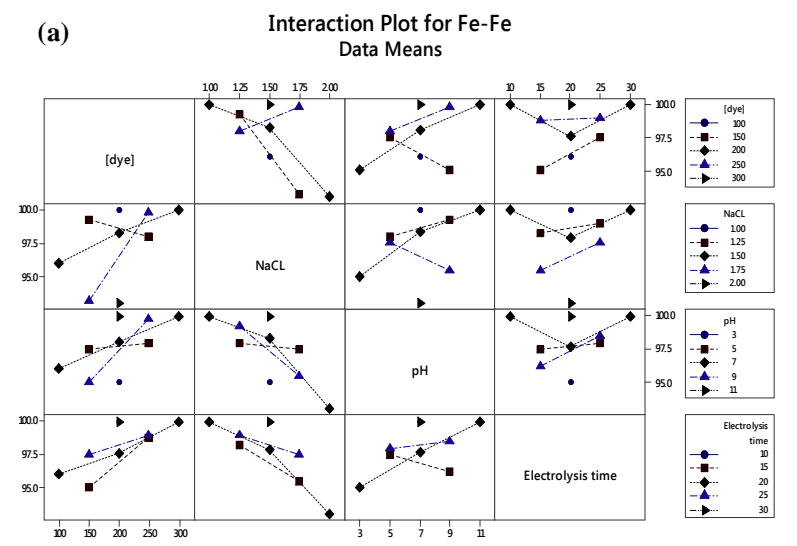

(b) Interaction Plot for Al-Al

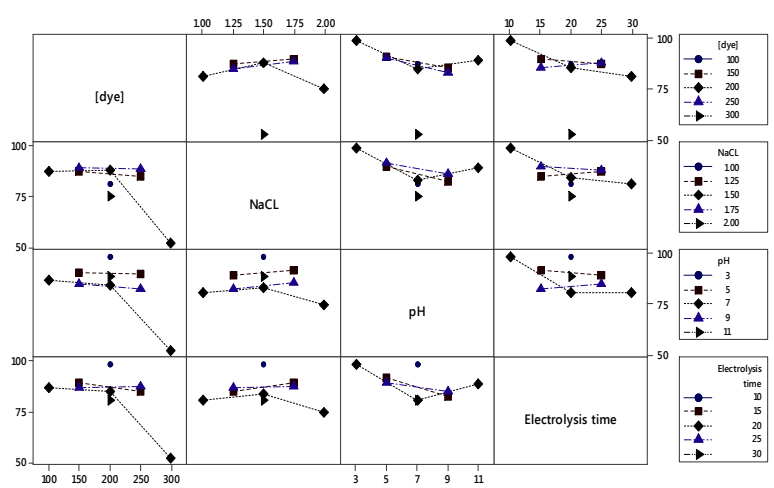

Figure 6. Interaction Plots

The effect of factors on the percent removal of Y145 dye using $\mathrm{Fe}-\mathrm{Fe}$ and $\mathrm{Al}-\mathrm{Al}$ electrode combinations.

\section{The effect of dye concentration}

To observe the effect of initial dye concentration on the removal of the dye using two electrode systems by EC, the experiments were carried out for five different dye concentrations $(100,150,200,250$ and $300 \mathrm{mg} / \mathrm{L})$. The higher removals of the dye were obtained using $\mathrm{Fe}-\mathrm{Fe}$ electrodes as compared to Al-Al electrodes. Furthermore, at the low concentration of the dye the removal was greater as compared to presence of the high concentration of the dye. Because, the high concentration requires the high quantity of coagulant for coagulation in a fixed period of time [25]. The effect of concentration of the dye combined with other factors on the removal efficiency of the dye is shown in Fig. 7, and Fig. 8.

\section{The effect of $\mathrm{NaCl}$}

The effect of amount of supporting electrolyte $(\mathrm{NaCl})$ on the removal of $\mathrm{Y} 145$ dye is given in Fig. 7 and 8. It can be ascertained from Fig. 7a-d that the dye removal efficiency was not increasing with an increase in the supporting electrolyte concentration in Fe-Fe electrode system while it was increasing using $\mathrm{Al}-\mathrm{Al}$ electrode system as shown in Fig. 8a-d. The formation of chlorine gas and $\mathrm{OCl}^{-}$owing to the oxidation of chloride ions at the anode, additionally, provides support for the removal of contaminants in the EC system. Thus, the supporting electrolyte not only 
increases the conductivity but also contributes as a strong oxidizing agent [26].

\section{The effect of $\mathrm{pH}$}

The $\mathrm{pH}$ of the EC system significantly affects the efficiency of EC process. The $\mathrm{pH}$ determines the type of hydroxide of metal cations in the EC system and also determines the interaction between the formed coagulants and the molecules of dye in the solution. Consequently, It influences the mechanism of the removal of dye from the aqueous system. In order to investigate the effect of the $\mathrm{pH}$ of the solution on the removal of the dye, the experiments were performed by adjusting the initial $\mathrm{pH}$ such as 3, 5, 7, 9 and 11 . Fig. 7 and Fig. 8 are showing that the removal of
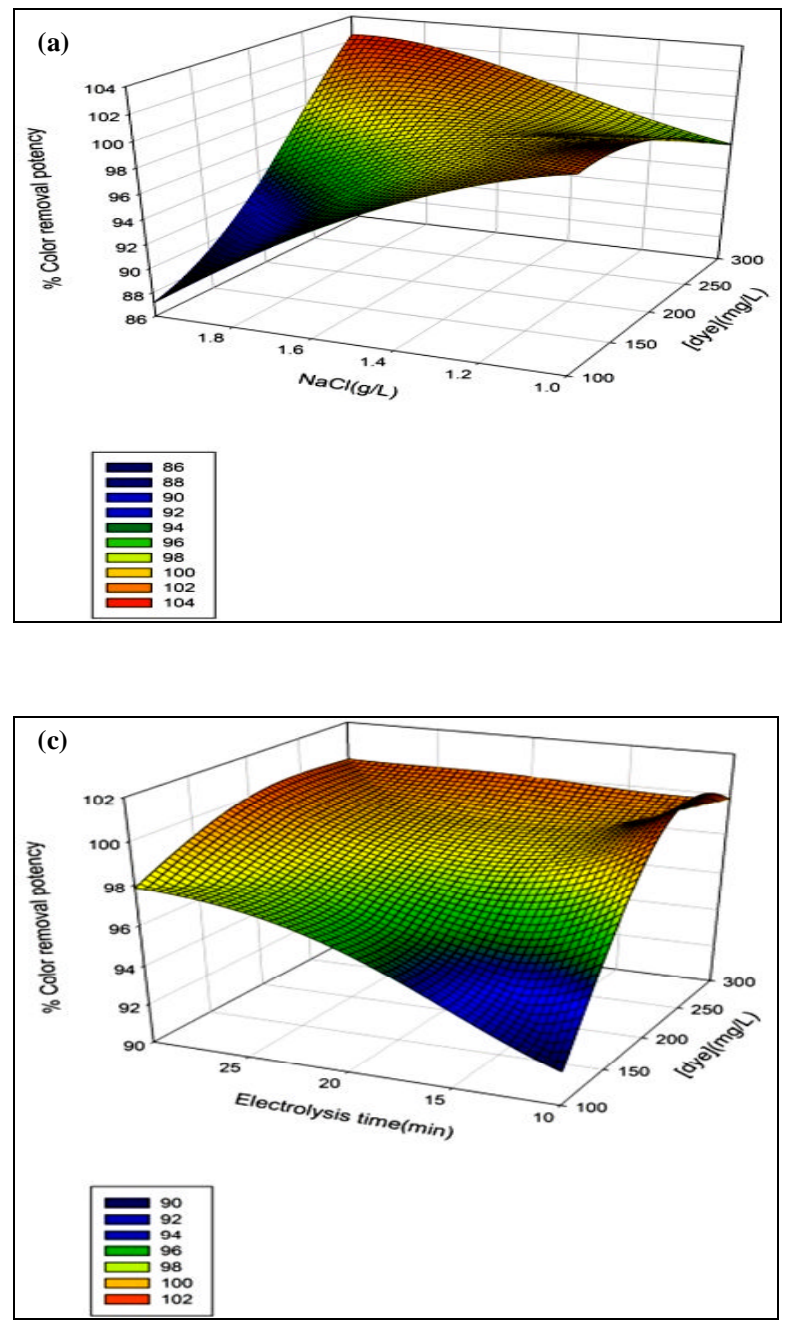

the dye was higher in the acidic condition as compared to the basic environment of the EC system. Because, the acidic condition increases the rate of formation of $\mathrm{Fe}^{+3}$ cations in the system [27]. The effect of $\mathrm{pH}$ of the dye solution combined with other factors on the removal efficiency of the dye is shown in Fig. 7 and 8.

\section{The effect of electrolysis time}

The removal efficiency of the dye was increasing with the increase of electrolysis time for both the electrode combinations. It was also in agreement with the reported data [28, 29]. The effect of electrolysis time combined with other factors on the removal efficiency of the dye is shown in Fig. $7-8$.
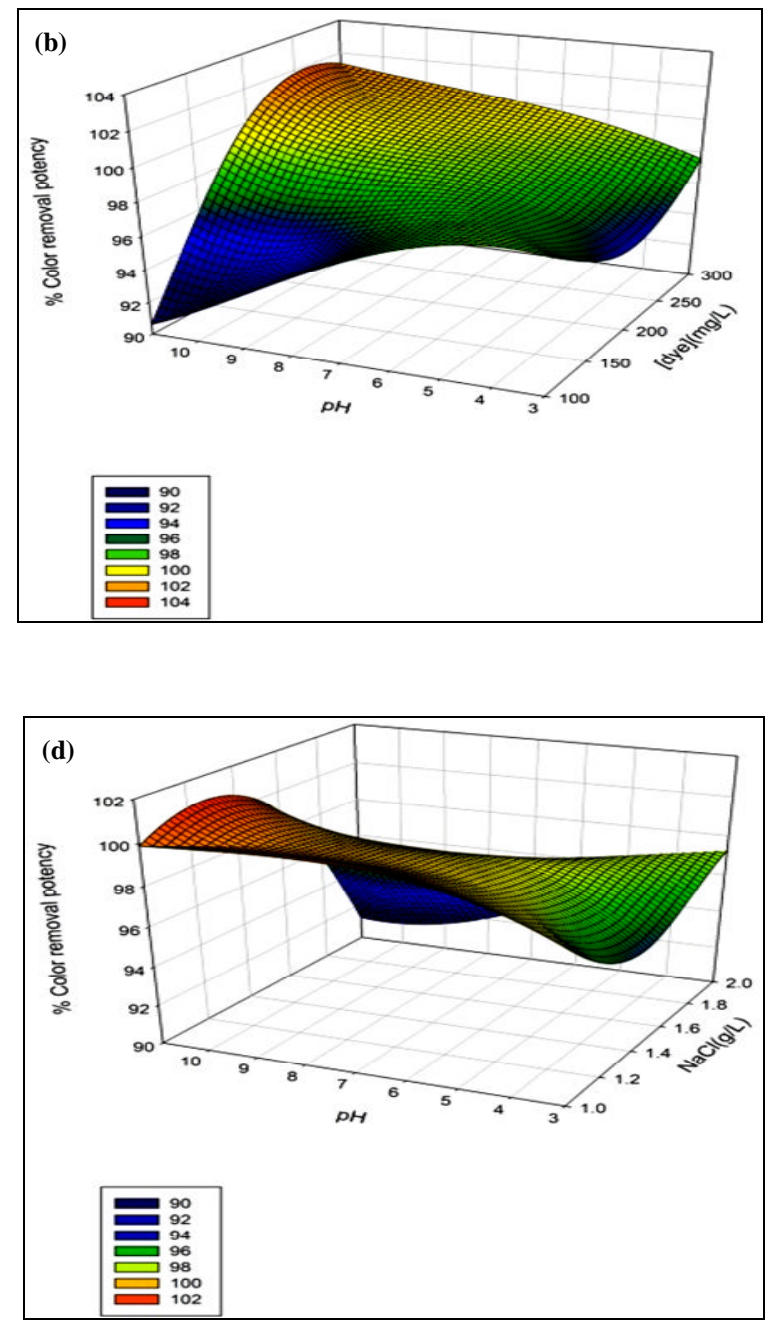

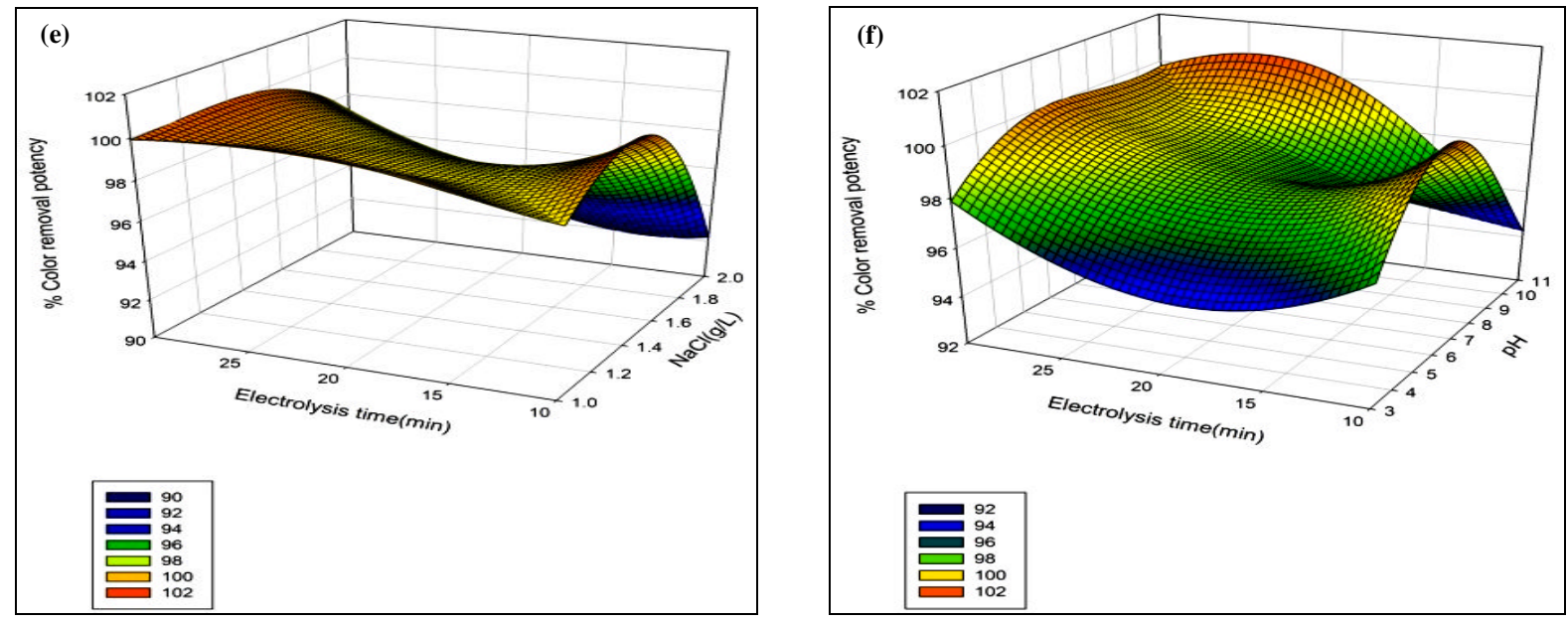

Figure 7. Response surface plots for the removal of Y145 dye using Fe-Fe electrodes
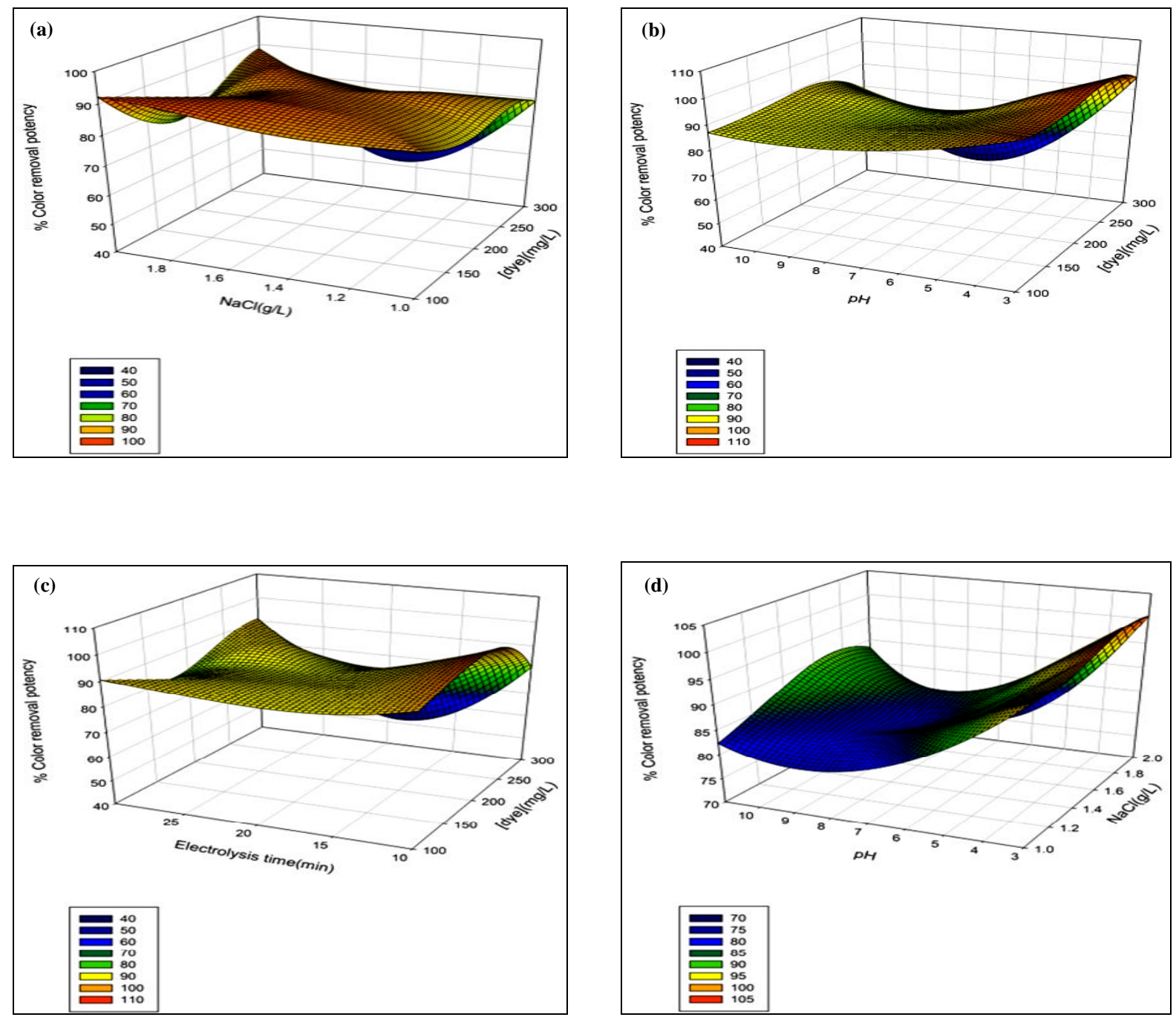

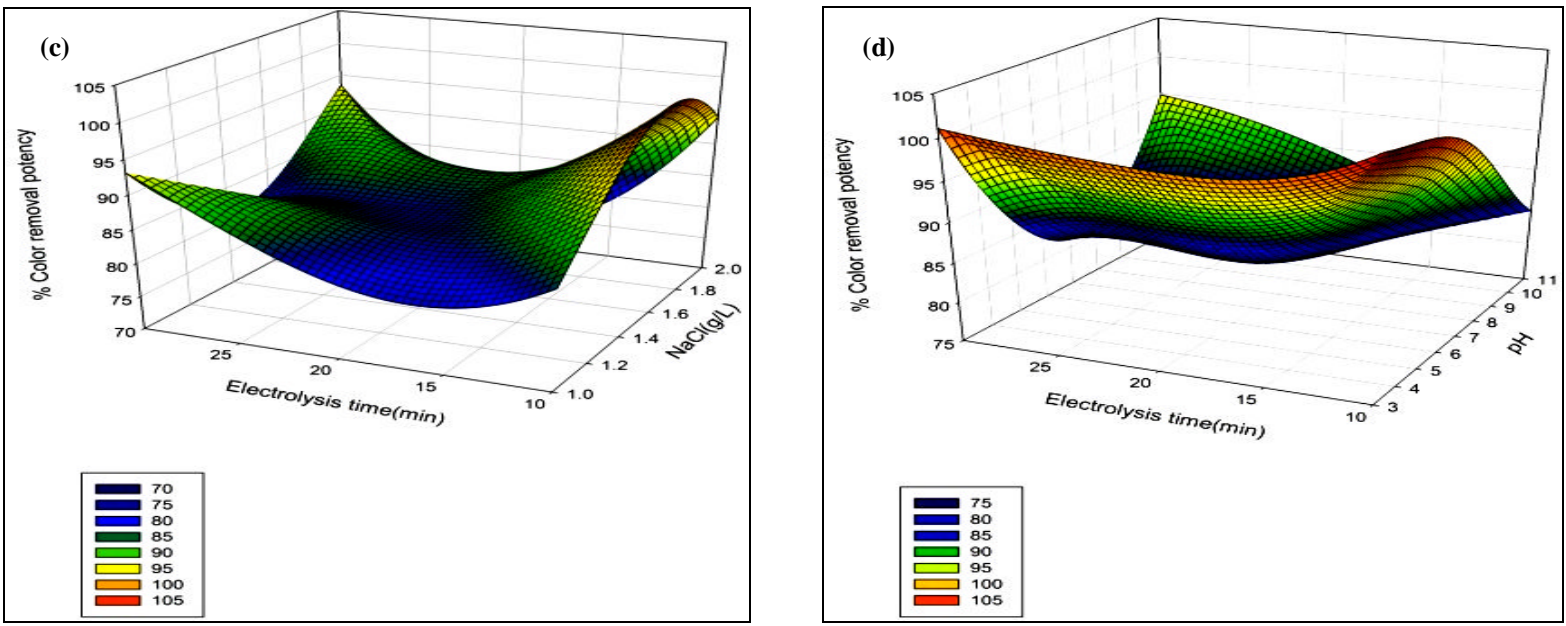

Figure 8. Response surface plots for the removal of Y145 dye using Al-Al electrodes

\section{The effect of nature of electrode system}

In $\mathrm{EC}$ process, the electrodes of $\mathrm{Al}$ and $\mathrm{Fe}$ were used. They are easily available, low cost, and undergo better dissolution [30]. The published data of some authors pointed out to the benefits of $\mathrm{Fe}$ electrodes, while others pointed out to the advantages of using $\mathrm{Al}$ anodes. It is also pointed out that $\mathrm{Fe}$ is relatively cheaper [31]. Fe forms more denser flocks of coagulated contaminants as compared to $\mathrm{Al}$ because it is heavy in mass [32]. Furthermore, $\mathrm{Fe}$ has better complex formation nature with inorganic/organic pollutants than $\mathrm{Al}$ [33]. However, it is also reported that $\mathrm{Al} / \mathrm{Al}$ electrode combinations effectively utilized for the removal of dyes and $\mathrm{Fe} / \mathrm{Fe}$ electrode worked better for $\mathrm{COD}$ and phenol removal, while $\mathrm{Al} / \mathrm{Fe}$ and $\mathrm{Fe} / \mathrm{Al}$ electrode combinations were successfully applied for the treatment of paper mill wastewater [34]. It is found that around 9 carbon atoms are complexed by one $\mathrm{Fe}$ atom, whereas 3 carbon atoms are allowed for complexation by an $\mathrm{Al}$ atom. It is also determined that "coordination" numbers of Fe or Al largely depend on the wastewater to be treated. Therefore, the efficiency of the type of electrode is depend upon the type of effluent [35]. In this work $\mathrm{Fe}-\mathrm{Fe}$ electrode system provided the data of higher removal of Y145 dye as compared to Al-Al electrode system. Therefore, $\mathrm{Fe}-\mathrm{Fe}$ electrode system will be proved more effective for the removal of the dye in the real effluent.

\section{FT-IR analysis}

Fig. 9 shows the FT-IR spectrum of Y145 dye. The IR absorption bands of Y145 dye are given in Table 6.

Table 6. The IR absorption bands for the given functional groups in the dye.

\begin{tabular}{cc}
\hline Functional groups & $\begin{array}{c}\text { Wave number } \\
\left(\mathbf{~ c m}^{-\mathbf{1}}\right)\end{array}$ \\
\hline $\mathrm{NH}$ & 3450 \\
$\mathrm{CH}$, Arom & 3096 \\
$\mathrm{C}=\mathrm{C}-$ & 1481 \\
$\mathrm{~N}=\mathrm{N}$ & 1435 \\
$-\mathrm{C}=\mathrm{N}-$ & 1587 \\
$\mathrm{C}-\mathrm{N}$ & 1221 \\
Sulfonates & $705-570$ \\
Disulfides (CS stretch) & $1130-1080 / 680-610$ \\
Sulfate ion &
\end{tabular}

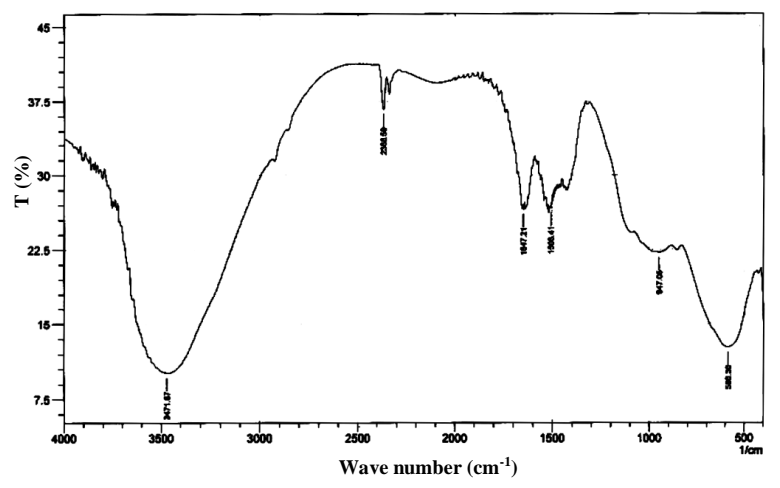

Figure 9. FT-IR spectrum of Y145 dye 


\section{Conclusion}

In the present study, CCD was successfully applied to optimize the parameters of the EC process for the removal of Y154 dye from the simulated wastewater using $\mathrm{Fe}-\mathrm{Fe}$ and $\mathrm{Al}-\mathrm{Al}$ electrodes. The optimum operating parameters for the $\mathrm{Fe}-\mathrm{Fe}$ electrode system were $100 \mathrm{mgL}^{-1}$ of dye concentration, $1.0 \mathrm{gL}^{-1}$ of $\mathrm{NaCl}, \mathrm{pH}$ of 5.0 and 30 min of electrolysis time. The maximum removal of the dye was found to be $99.21 \%$. On the other hand, the optimum operating parameters for the Al-Al electrode system were $120 \mathrm{mgL}^{-1}$ of dye concentration, $1.66 \mathrm{gL}^{-1}$ of $\mathrm{NaCl}, \mathrm{pH}$ of 3.0 and 10 min of electrolysis time. The percent removal of the dye was found to be $98.24 \%$. Furthermore, It was also encountered that the concentration of the dye (A), amount of electrolyte (B) were showing linearly and combined effect on the removal of the dye in $\mathrm{Fe}-\mathrm{Fe}$ electrodes system. In the second electrode system, the concentration of the dye (A) has a linear and quadratic effect on the removal of the dye. It is concluded that the process can be effectively applied for the removal of Y145 dye from wastewater at large scale.

\section{Acknowledgment}

The author acknowledges the financial assistance from the University of Karachi, Karachi, Pakistan.

\section{References}

1. K. S. Hashim and N. H. Al-Saati, Mater. Sci. Eng., 584 (2019) 012024). https://doi.org/10.1088/1757899X/584/1/012024

2. B. A. Abdulhadi and P. Kot, Mater. Sci. Eng., 584 (2019) 012035.

https://doi.org/10.1088/1757$\underline{\text { 899X/584/1/012035 }}$

3. N. H. Bektaş, H. Akbulut, H. Inan and A. Dimoglo, J. Hazard. Mater., 106 (2004)101. https://doi.org/10.1016/j.jhazmat.2003.10.00 2

4. A. K. Golder, A. N. Samanta and S. Ray. Sep. Purif. Technol., 52 (2006) 102. https://doi.org/10.1016/j.seppur.2006.03.027
5. A. A Bassam, Y. Yavuz and A. S. Koparal. Sep. Purif. Technol., 86 (2012) 248. https://doi.org/10.1016/j.seppur.2011.11.011

6. M. Bayramoglu, M. Eyvaz and M. Kobya. Chem. Eng. J., 128 (2007) 155. https://doi.org/10.1016/j.cej.2006.10.008

7. K. Garg and B. Prasad. Environ. Technol. Innov., 8 (2017) 191. https://doi.org/10.1016/j.eti.2017.07.001

8. M. Y. A. Mohammad, P. Morkovsky, J. A. G. Gomes, M. Kesmez, J. Parga and D. L. Cocke. J. Hazard. Mater., 114 (2004) 199. https://doi.org/10.1016/j.jhazmat.2004.08.009

9. L-H, Ivonne, C. B. Díaz, G. R. Morales, B. Bilyeu and F. Ureña-Núñez. Chem. Eng. J., 148 (2009) 97. https://doi.org/10.1016/j.cej.2008.08.007

10. A. R. Shah, T. Hajira and H. M. Kifayatullah. Desali. Water Treat., (2017) 72. doi:10.5004/dwt.2017.21604

11. E. Gengec, M. Kobya, E. Demirbas, A. Akyol and K. Oktor. Desalination, 286 (2012) 200. https://doi.org/10.1016/j.desal.2011.11.023

12. APHA, AWWA, WPCF, Standard Methods for the Examination of Water and Wastewater, 21st ed., American Public Health Association, Washington, DC, (2005).

https://www.worldcat.org/title/standardmethods-for-the-examination-of-water-andwastewater/oclc/156744115

13. N. A. Daneshvar, Oladegaragoze and N. Djafarzadeh. J. Hazard. Mater., 129 (2006) 116. https://doi.org/10.1016/j.jhazmat.2005.08.03 $\underline{3}$

14. A. R. Shah, T. Hajira and H. M. Kifayatullah. Int. J. Environ. Sci. Nat. Res., 2 (2017) 555583.

https://pdfs.semanticscholar.org/8c10/549f87 64f65d4057ccfca79cb82768cfb67b.pdf

15. A. Gürses, M. Yalçin and C. Doğar. Waste Manage., 22 (2002) 491. https://doi.org/10.1016/S0956053X(02)00015-6

16. M. Rebhun and M. Lurie. Water Sci. Technol., 27 (1993) 1. https://doi.org/10.2166/wst.1993.0260 
17. M-F. Pouet and A. Grasmick. Water Sci. Technol., 31 (1995) 275. https://doi.org/10.2166/wst.1995.0536

18. S. Bajpai, S. K. Gupta, A. Dey, M. K. Jha, Vidushi Bajpai, Saurabh Joshi and Arvind Gupta. J. Hazard. Mater., 227 (2012) 436. https://doi.org/10.1016/j.jhazmat.2012.05.01 $\underline{6}$

19. M. Kumar, F. I. A. Ponselvan, J. R. Malviya, V. C. Srivastava and I. D. Mall. J. Hazard. Mater., 165 (2009) 345.

https://doi.org/10.1016/j.jhazmat.2008.10.04 1

20. Kumar, Mayank, F. Infant Anto Ponselvan, Jodha Ram Malviya, V. C. Srivastava and Indra Deo Mall. J. Hazard. Mater., 165 (2009) 345.

https://doi.org/10.1016/j.jhazmat.2008.10.04 $\underline{1}$

21. K. S. Ravikumar, S. Krishnan, Ramalingam, and K. Balu. Dyes Pigm., 72 (2007) 66. https://doi.org/10.1016/j.dyepig.2005.07.018

22. X. Jing, Y. Cao, X. Zhang, D. Wang, X. Wu, and H. Xu. Desalination, 269 (2011) 120. https://doi.org/10.1016/j.desal.2010.10.050

23. G. Güven, A. Perendeci and A. Tanyolaç. $J$. Hazard. Mater., 157 (2008) 69. https://doi.org/10.1016/j.jhazmat.2007.12.08 $\underline{2}$

24. K. B. Körbahti and M. A. Rauf. Chem. Eng. J., 136 (2008) 25. https://doi.org/10.1016/j.cej.2007.03.007

25. I. Arslan-Alaton, M. Kobya, A. Akyol and M. Bayramoğlu. Color. Technol., 125 (2009) 234.

https://doi.org/10.1111/j.14784408.2009.00202.x
26. H. Zhang, X. W. Yanli Li, Y. Zhang and D. Zhang, Waste Manage., 30 (2010) 2096. https://doi.org/10.1016/j.wasman.2010.04.02 $\underline{9}$

27. J. Ge, J. Qu, P. Lei and H. Liu., Sep. Purif. Technol., 36 (2004) 33. https://doi.org/10.1016/S13835866(03)00150-3

28. D. Ghosh, C. R. Medhi and M. K. Purkait, Chemosphere, 73 (2008) 1393.

https://doi.org/10.1016/j.chemosphere.2008. 08.041

29. Y. Yavuz, E. Öcal, A. S. Koparal and Ü. B. Ögüutveren. J. Chem. Technol. Biotechnol., 86 (2011) 964.

https://doi.org/10.1002/jctb.2607

30. G. Mouedhen, M. Feki, M. D. P. Wery and H. F. Ayedi. J. Hazard. Mater., 150 (2008) https://doi.org/10.1016/j.jhazmat.2007.04.09 $\underline{0}$

31. M. Solak, M. Kılıç, Y. Hüseyin and A. Şencan. J. Hazard. Mater., 172 (2009) 345. https://doi.org/10.1016/j.jhazmat.2009.07.01 $\underline{8}$

32. O. Sahu, B. Mazumdar and P. K. Chaudhari. Environ. Sci. Pollut. Res., 21 (2014) 2397. https://doi.org/10.1007/s11356-013-2208-6

33. S. Vasudevan and A. Mehmet. Oturan. Environ. Chem. Lett., 12 (2014) 97. https://doi.org/10.1007/s10311-013-0434-2

34. S. Bellebia, S. Kacha, Z. Amel, Bouyakoub and Z. Derriche. Environ. Prog. Sustain. Energy, 31 (2012) 361. https://doi.org/10.1002/ep.10556

35. A. K. Chopra and A. K. Sharma. Appl. Water Sci., 3 (2013) 125. https://doi.org/10.1007/s13201-012-0066-X 